\title{
The Study of Physical Growth and Nutritional Status among the Chakhesang Boys of Sudzulhou Village, Dimapur District, Nagaland
}

\author{
Mr.Thangboy Kuki \\ Phd. Scholar Department of Anthropology North Eastern Hill University (NEHU) Shillong, Meghalaya-22
}

\section{Introduction}

The study of human growth and development is an important field of anthropological research. By the term growth, we mean "quantitative increase in size or mass" of an organism; while development refers to "progression of changes either quantitative or qualitative that leads from an undifferentiated or immature state to a highly organized, specialized, and mature state" (Bogin, 1999). According to Garn (1995), "Growth, is a human characteristic and varies with sex and ages as well as between different ethnic groups and different acculturation level is a natural phenomenon". It is an exceeding regular process refers to the continuous addition in body dimension of an organism over a period of time.

The rate of growth of various components of an organism may have important in its ability to adapt to the environment and hence may play a role in evolution. "Human bio-cultural evolution produced the pattern of growth and development that converts a single fertilized cell with its compliment of deoxyribonucleic acid (DNA) into a multicellular organism composed of hundreds of different tissues, organs, behavioural capabilities and emotions" (Bogin, 1999). According to Garn (1952), "The term growth and development as used in physical studies refers to the process intimately linked in time but partially independent, unquestionably genetically determined yet uniquely susceptible to environmental modifications". The study of growth is important in elucidating the mechanism of evolution, for the evolution of morphological characters necessarily comes about through alteration in the inherited pattern of growth and development. Growth also occupies an important place in the study of individual differences in form and function of man, for many of these also varies through differential rates of growth of particular parts of the body relative to others" ( Tanner, 1998). Since human growth and development is also largely influenced by socio-environmental factors like nutrition, infection, income, occupation, and religion, it is very vital for understanding the bio-cultural variation and evolution of human population (Tanner, 1998; Eveleth and Tanner, 1990).

The process of growth is highly organized. A child is to grow a long pre-destined curve under optimal environmental conditions. There is a complex interaction between the genetic makeup of a person and his environment. While the favourable and optimal environmental factor help to accomplish that target. The children usually follow any line in the standards for judging the growth of the children with regards to their population, age, and sex specifically. Only during adolescence do the children sometimes wander across the lines of growth norms, whereas, at all other ages they generally follow a given gentile, this deviation during adolescence happen because there are some children who enter their adolescence spurts earlier or later than the others of their age. During the whole development period between infancy and maturity, many demands are made on the growing child by its environment. Although we may consider that much of the child's response to new situation is genetically programmed its continuing growth and ability to survive depends on a rebilient and adaptable physiology working to sustain greater mobility. This mobility is gradually attained by the extension and growth on its various organs and segments are not parallel but move at different speeds from each other (Croney, 1981).

A growing child exhibits a gradual change in appearance and shape superficially it can be seen that parts of the body are growing faster than others. A good example of this can be readily seen in the head where it can be observed that for many years during early childhood, the rate remains relatively small in relation to the rapid increase of size of the cranium. The sexual reproductive systems waits until later, when sometime about or after eleven years it makes fairly rapid growth and the difference between the sexes become steadily more manifested, body weight shows a steady increase until about the sixth or seventh year of life when it is rather less than $50 \%$ of the adult value. From seven to eleven years it almost marks time and so increase very little. There is often a wide variation of speed of growth between body parts and always form variations while growth takes place. Externally this means that child's body is liable and prone to change and that these changes are normal and build up, stage by stage, towards a balanced mature condition. The variation of the speed of growth between one body and another is regulated so that each part reaches its size, proportional to the role it has to 
play in the body's physiology at the correct time. The glands provide the secretary centre's which release hormones stimulate the growth of particular tissues. One part of the brain, the hypothalamus is the controller of these functions.

During growth the bones of the skeleton undergo changes of proportion both with and without deformation in cartilage growth plates. The law of alteration of growth can be seen to be clearly operating in the change of proportion taking place during the growth of the long bones of the skeleton. It can be considered that the long bones thicken for as period ranging from 4-6 months. For example, the femur bone of the leg thickens while the tibia and fibula bones lengthen. Throughout the growing period, there is an extensive remodelling is paced by growth alteration takes place in the external forms of the body.

In infancy there is a general chubbiness with relatively large dimensions of the trunk and head. The upper part of the body is proportionately then the lower. The cranium length, breadth, and circumference are about $96 \%$ of the adult value by ten years of age. During pre-adolescent year growth is largely concerned with building up, a strong skeleton and extending tissues. The period of puberty comes at different times for boys and girls, girls being something like two years ahead of boys. Girls are generally heavier, taller and have a greater body surface area than boys in the early pre-pubertal period, but are then generally lighter than boys to puberty. Boys begin to assume extra weight in the later pre-pubertal period. During the period of the adolescence growth spurt, there is a very marked increase in size of body parts. The spurt of growth starts with an increase in foot length. In general, growth spurts commence in the distal segments of the appendicle skeleton and proceed through to more.

Interestingly, during adolescent period the boys and girls can be seen in all stages of their development. For example, at 14 years, in any population there will be certain member of who are still to enter their adolescent of pubertal periods. They will look like pre-adolescent children having no growth of sexual hair, and no abrupt increase in height. There can be another group of children midway through their adolescent cycle. They may show certain level of development of sexual maturation characteristics and may exhibit increased velocities. Still some other may have completed their full sexual growth. The children who enter adolescent later are called 'late matures' and those entering early are referred to as 'early matures'. There is no indication that late matures will end up smaller than their counterparts, rather they will entry of various pubertal characteristic exist but the duration of various development stages and complete maturation processes also vary greatly. It is largely of their genetic make-up which sets up the tempo of growth and development.

A child's rate of development depends mainly on the following factors: a. hormones, b. genetics, c. race and climate, $d$. nutrition, e. socio-economic class and size of the family, and f. illness. The most important controlling factor, thyroid hormones plays a vital role throughout the whole process of growth. In hypothyroidism growth is delayed; skeletal maturity, dental maturity, and growth of the brain are all affected. The genetically control of growth rate is manifested most simply in the inheritance of age at menarche. This genetically control operates through the whole period of growth. There are racial differences in the rate and pattern of growth, leading to the differences seen in adult build, some of these are clearly genetically determined, while other depend perhaps on climate differences. Nutrition is another major factor in growth process. An adequate amount of diet during the child's formative period may produce lasting results. Many children are stunted because of the lack of vitamins, essential mineral, and other constituents of balanced diet. Evidence of the effect of malnutrition is slowing growth and development is seen, if after a short period of malnutrition condition is improved, growth is accelerated and the child catches up the normal growth of the body.

Growth studies have been an essential part of anthropological research since the birth of the discipline itself. Early anthropologist, especially Franz Boas are well known for their contribution to growth studies. One of the main reasons for such an interest in growth studies is that human growth serves as a mirror that "reflects the bio-cultural evolution of species" (Bogin, 1999). Of course, the basic objective of anthropology is to understand the biological and cultural evolution of human population. Besides, growth study gives the understanding of not only the health and nutritional status of a population, but also the interaction between and their biology and culture.

\section{The Main Objectives:}

1. To assess the growth pattern of the Chakhasang Boys aged 7 to 18 years old in terms of anthropometric variables by cross-sectional studies.

2. To assess the nutritional status of these children, using certain anthropometric indices.

3. To compare the studied population group with those children reported from other populations, especially in North-East India. 


\section{Land and People:}

The present study has been conducted in a village known as Sodzulhou which falls under Dimapur district, one of the eleven districts of Nagaland. This village is situated at the outskirt of the Dimapur town. The village boundaries are, to the East- Diphu River; West- National Highway 39; North- $7^{\text {th }}$ Mile Village and South- $7^{\text {th }}$ Mile Model Village. The word "Sudzulhou" is derived from the word "Sodzu" meaning "far distance" and "Ihou" meaning, "dwell". Thus the "Sodzulhou Village" means the villagers migrated from far distance. This is a village inhabited by the Chakhesang people. An interesting feature of this village is that majority of the people have migrated from one village known as Khezhakheno Village under Phek district and settled here as a homogenous group. Almost the whole population of this village traces their origin form Khezhakheno village. The first settlers of this village migrated from the legendary village and settled here six decades ago.

The state of Nagaland has a total area of 16,579 sq.kms. Kohima is the state capital which is about $1,444,12 \mathrm{~m}$ above sea level. According to the census 2001, the population of the state is $19,88,636$. The density of population is 120 per sq.km. The sex ration is $909: 1000$ (female:male). The overall literacy rate is $67.11 \%$ while in male it is $71.77 \%$ and in female it is $61.92 \%$. The biggest village is the Kohima Village the state has eleven districts- Kohim, Mokukchung, Tuensang, Mon, Wokha, Zunheboto, Phek, Dimapur, Peren, Longleng, and Kiphire. The tribes of Nagaland are Angami, Ao, Chakheshang, Chang, Khiamniungan, Konyak, Lotha, Phom, Pochury, Rengma, Sumi, Sangtam, Yimchungru, Zeliang, Kachari, and Kuki.

\section{Brief History of the Village:}

In 1948, the then Assam Government (Naga Hills) allotted some land to Late Mr.Kodolhou S/O Late Chilo, Mr.Vivotso S/O Late Thorhu and Late Ngochinyi (Mora) S/O Late Pou after their retirement from the Army, along the NH. No. 39 which is $7^{\text {th }}$ miles from Dimapur was covered by thick forest and a number of wild animals particularly wild elephants disturbed human cultivation and often destroyed their paddy fields and settlements. Subsequently, they returned to Khezhakhano village for good without much dividend. However, Mezelhou S/O Chilo along with his family members migrated from the legendary village known as Khezhakheno under Phek district which is about $180 \mathrm{~km}$ from Dimapur and settle down at the site where the three earlier villages had attempted to start a settlement area in the year 1949. Mezelhou then called AphuKoza S/O Late DiloKoza and his family to come to Dimapur the same year. From there they started searching for a better place to establish a village and in the process occupied the present $7^{\text {th }}$ mile village and Sodzulhou village area. Unfortunately one night Mezelhou was badly injured by wild elephant while guarding hi paddy field and he succumbed to his injuries. His mortal remain was buried at the present village site in 1963.

The Sodzulhou village gazetteer letter No. is K-120 and it was established in 1963. In the year 1972 the village was declared Government recognized village. This village is the first and oldest village among the Chakhesang villages in Dimapur.

\section{Language:}

The dominant language spoken by the people of Sodzulhou village is Khezha language. Nagamese a lingua franca is also very commonly used by the people while communicating with non-local people and also within themselves.

\section{Food Habits:}

Rice is their most staple food. They are also fond of non-vegetarian foods which include Pork, Chicken, Fish, and Beef etc. At the same time they also consume lots of green vegetables and fruits. Dry fish and dry meat are also important items. Cooking is usually simple without or minimum oil and spices. Boiled vegetables are also considered as indispensable item of a perfect meal. Tea is their favourite beverage which they take three to four times a day.

\section{Religion:}

From the data collected on the religion of Sodzulhou dwellers, all the Chakhesang with few non-local dwellers are Christian. Non-local dwellers belong either to Hindu or Islam.

\section{Dress and Ornaments:}

Like any other parts of this country the impact of westernization and modernization is clearly observed in this village as well. Traditional dress and ornaments can be seen only in certain occasions. In daily life they wear non-traditional dresses like pant and shirts by male and skirts, jeans and shirts by female. Occasionally, females wear mekhela (miniyie) and shawl (raa), men wear upper garment (khra) and lower garment (chechomona). 


\section{Materials and Methods:}

The data for the present study has been collected from the Chakhesang boys of Sudzulhou Village of Dimapur district. The study comprises of cross-sectional data on a total of 200 boys subject, age group of 7 to 18 years. The age groups are based on decimal age following table given by Weiner and Lourie (1981). A total of 7 anthropometric measurements: Height vertex, Sitting height vertex, Biacromial diameter, Maximum hip breadth, Upper arm circumference, Head circumference, and Weight were made on a total of 200 boys following the standard procedure given by Weiner and Lourie (1981). Before taking the measurements some necessary information such as name, date of birth, religion, clan, and mothers and fathers name and occupation, total family income and expenditure, total family members etc. were recorded. The measurements were taken with knowledge from the child's parents or senior members of the family and most with minimum clothing.

The data collected were subjected to statistical analysis such as mean, standard deviation, standard error mean, co-efficient of variation and range, in order to arrive at suitable interpretation. Student's t-test was also applied to the find the difference (if any). The result of the present study have been compared with the ICMR data at $50^{\text {th }}$ percentile, the Khasi boys of East Khasi Hills and Garo boys of Ri-bhoi district, Meghalaya.

\section{Observation}

After the statistical analysis of the raw data the following results have been drawn. In order to show the growth trend, the tabulation figures are presented in graphic forms. These graphs depict the 'mean course' of growth for all measurements. The graphs have been plotted in order to perceive the growth rate between the age groups of Chakhesang boys within the age group 7 to 18 years. The mean, standard error of mean, standard deviation, co-efficient variation, and ranges of various anthropometric variables in different age groups are present in the tables and the distance and velocity curves in the figures.

Height:

Table1. Age group distribution of mean, SD, CV, Range and SEM for Height Vertex (cm)

\begin{tabular}{|c|c|c|c|c|c|c|c|c|}
\hline $\begin{array}{l}\text { Age in } \\
\text { years }\end{array}$ & Mean & $\begin{array}{c}\text { Increment per } \\
\text { year }\end{array}$ & $\mathrm{N}$ & SD & $\mathrm{CV}$ & Min. range & Max. range & SEM \\
\hline 7 & 112.55 & & 18 & 1.14 & 1.30 & 110.2 & 114.2 & 0.26 \\
\hline 8 & 117.37 & 4.82 & 16 & 0.77 & 0.59 & 116.7 & 119.9 & 0.19 \\
\hline 9 & 123.06 & 5.68 & 17 & 1.19 & 1.43 & 120.2 & 124.4 & 0.29 \\
\hline 10 & 129.7 & 6.63 & 16 & 1.47 & 2.16 & 129.3 & 134.6 & 0.36 \\
\hline 11 & 136.49 & 6.79 & 16 & 2.24 & 5.04 & 132.5 & 104.1 & 0.56 \\
\hline 12 & 140.86 & 4.37 & 18 & 2.23 & 5.00 & 136.9 & 144.8 & 0.52 \\
\hline 13 & 144.72 & 3.85 & 15 & 2.37 & 5.65 & 139.9 & 147.9 & 0.61 \\
\hline 14 & 150.41 & 5.69 & 16 & 1.72 & 2.98 & 150.5 & 155.6 & 0.43 \\
\hline 15 & 157.04 & 6.63 & 17 & 1.16 & 1.36 & 155.5 & 159.2 & 0.28 \\
\hline 16 & 160.77 & 3.72 & 17 & 3.98 & 15.88 & 155.1 & 168.4 & 0.96 \\
\hline 17 & 161.28 & 0.51 & 17 & 3.16 & 10.03 & 153.8 & 167.6 & 0.76 \\
\hline 18 & 161.32 & 0.04 & 17 & 3.79 & 14.38 & 154.2 & 167.9 & 0.91 \\
\hline Total & & & 200 & & & & & \\
\hline
\end{tabular}

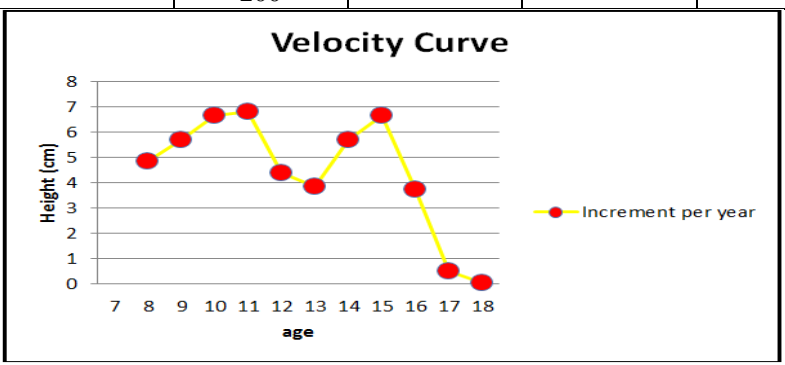

Figure1.1 Velocity Curve for Height Vertex

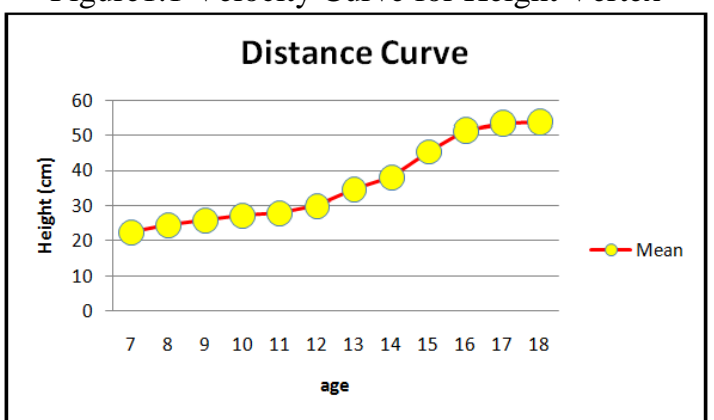

Figure1.2 Distance Curve for Height Vertex 
The height vertex of stature between 7 to 18 years of the present study can be observed from the table 1 and figure 1.2. There is a general increase in the stature corresponding with their age. From the table it is seen that at the age 15 years the height increases more than the other age group therefore, the increase in height is maximum at the age of 15 years. Maximum increment shown is 6.63 . The minimum height is $110 \mathrm{~cm}$ and the maximum height is $167 \mathrm{~cm}$.

The annual increment or growth rate in height can be observed in figure 1.1. It can be observed that the growths in height were slightly decreased in the age 13 years but after which the growth gradually increases. The maximum increase is at the age 15 years with the velocity gain in height is $6.63 \mathrm{~cm}$ at that age. It can be said that the growth spurt occurs at 15 years.

Sitting Height:

Table2. Age group distribution of mean, SD, CV, Range and SEM for Sitting Height (cm)

\begin{tabular}{|c|c|c|c|c|c|c|c|c|}
\hline $\begin{array}{c}\text { Age in } \\
\text { years }\end{array}$ & Mean & $\begin{array}{c}\text { Increment per } \\
\text { year }\end{array}$ & $\mathrm{N}$ & $\mathrm{SD}$ & $\mathrm{CV}$ & Min. range & Max. range & SEM \\
\hline 7 & 57.12 & & 18 & 3.60 & 13.03 & 51.2 & 62.5 & 0.85 \\
\hline 8 & 59.16 & 2.04 & 16 & 3.61 & 13.05 & 54.3 & 66.9 & 0.90 \\
\hline 9 & 62.62 & 3.46 & 17 & 3.89 & 15.16 & 59.2 & 74.1 & 0.94 \\
\hline 10 & 65.26 & 2.63 & 16 & 3.69 & 13.62 & 59.3 & 75.2 & 0.92 \\
\hline 11 & 68.48 & 3.22 & 16 & 5.31 & 28.21 & 63.5 & 85.8 & 1.32 \\
\hline 12 & 69.93 & 1.45 & 18 & 3.72 & 13.84 & 66.2 & 81.8 & 0.87 \\
\hline 13 & 72.24 & 2.30 & 15 & 2.99 & 8.95 & 66.9 & 77.4 & 0.77 \\
\hline 14 & 74.28 & 2.04 & 16 & 5.28 & 27.90 & 71.9 & 84.5 & 1.32 \\
\hline 15 & 78.51 & 4.22 & 17 & 6.88 & 47.39 & 62.1 & 87.6 & 1.66 \\
\hline 16 & 80.35 & 1.84 & 17 & 3.10 & 9.64 & 74.1 & 86.3 & 0.75 \\
\hline 17 & 82.07 & 1.72 & 17 & 1.67 & 2.79 & 78.2 & 83.7 & 0.40 \\
\hline 18 & 85.2 & 3.12 & 17 & 2.64 & 7.01 & 80.3 & 89.2 & 0.64 \\
\hline Total & & & 200 & & & & \\
\hline
\end{tabular}

\section{Velocity Curve}

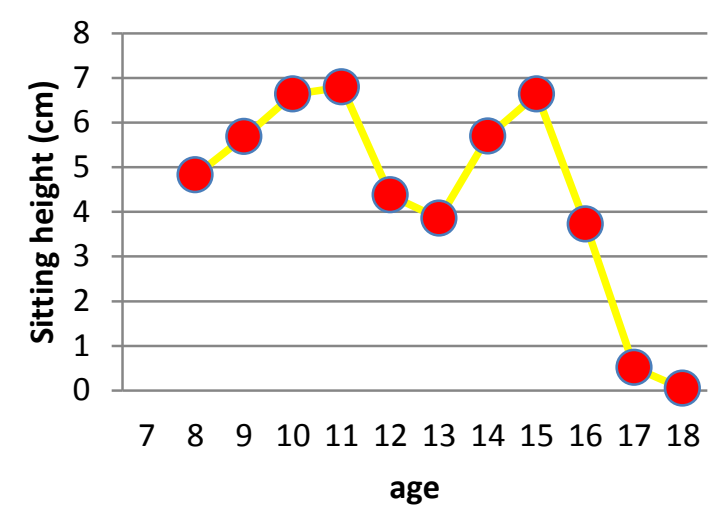

Increment per year

Figure2.1 Velocity Curve for Sitting Height

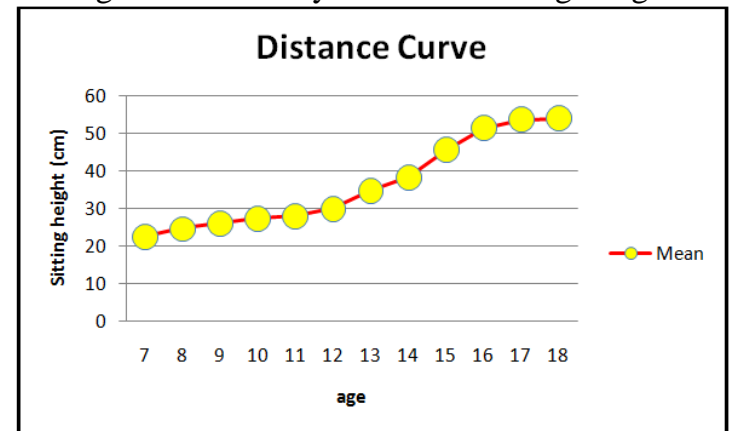

Figure2.2 Distance Curve for Sitting Height

The distance curve for sitting height for the present study is given in figure 2.2 and 2.1 gives the corresponding velocity curve both data are in the table no. 2 . The distance curve show that there is gradually increase in sitting height with increase in age in years. The maximum increment is found in the age 15 years 
with the difference of 4.22 , the minimum observed measurement of sitting height is $51.2 \mathrm{~cm}$ and the maximum measurement obtained is $89.2 \mathrm{~cm}$.

From the velocity curve, gain in sitting height is observed continuously. While there is a sharp rise in the curve at age 9 years and 15 years with a sharp slows down at the age of 12 years. The maximum increment gain is at the age of 15 years with $4.22 \mathrm{~cm}$. It can be said that the growth spurt occurs at 15 years.

Biacromial Diameter:

Table3. Age group distribution of mean, SD, CV, Range and SEM for Biacromial Diameter (cm)

\begin{tabular}{|c|c|c|c|c|c|c|c|c|}
\hline Age in years & Mean & $\begin{array}{c}\text { Increment } \\
\text { per year }\end{array}$ & $\mathrm{N}$ & $\mathrm{SD}$ & $\mathrm{CV}$ & Min. range & Max. range & SEM \\
\hline 7 & 25.3 & & 18 & 1.25 & 1.57 & 23.4 & 27.9 & 0.29 \\
\hline 8 & 25.96 & 0.66 & 16 & 1.13 & 1.28 & 23.7 & 27.9 & 0.28 \\
\hline 9 & 26.83 & 0.87 & 17 & 2.12 & 4.51 & 21.8 & 30.4 & 0.51 \\
\hline 10 & 27.15 & 0.31 & 16 & 1.39 & 1.95 & 24.2 & 30.1 & 0.34 \\
\hline 11 & 28.18 & 1.03 & 16 & 1.09 & 1.19 & 26.1 & 30 & 0.27 \\
\hline 12 & 29.45 & 1.27 & 18 & 1.72 & 2.97 & 25.7 & 33.2 & 0.40 \\
\hline 13 & 30.85 & 1.39 & 15 & 2.75 & 7.61 & 23 & 34.6 & 0.71 \\
\hline 14 & 32.50 & 1.65 & 16 & 2.04 & 4.18 & 29.1 & 36.1 & 0.51 \\
\hline 15 & 35.19 & 2.68 & 17 & 3.97 & 15.8 & 26.3 & 38.5 & 0.96 \\
\hline 16 & 36.27 & 2.08 & 17 & 3.42 & 11.69 & 29.3 & 39.3 & 0.82 \\
\hline 17 & 37.53 & 1.25 & 17 & 1.63 & 2.67 & 34.3 & 39.9 & 0.39 \\
\hline 18 & 38.38 & 0.85 & 17 & 3.56 & 12.70 & 26.7 & 40.9 & 0.86 \\
\hline Total & & & 200 & & & & \\
\hline
\end{tabular}

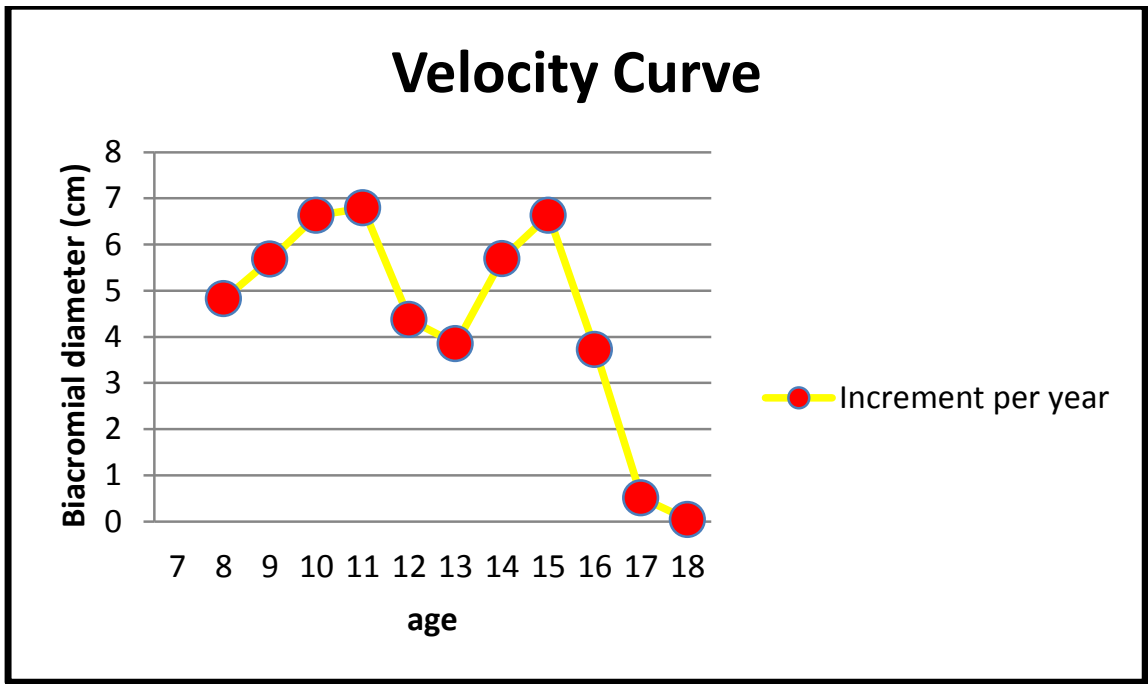

Figure3.1 Velocity Curve for Biacromial Diameter

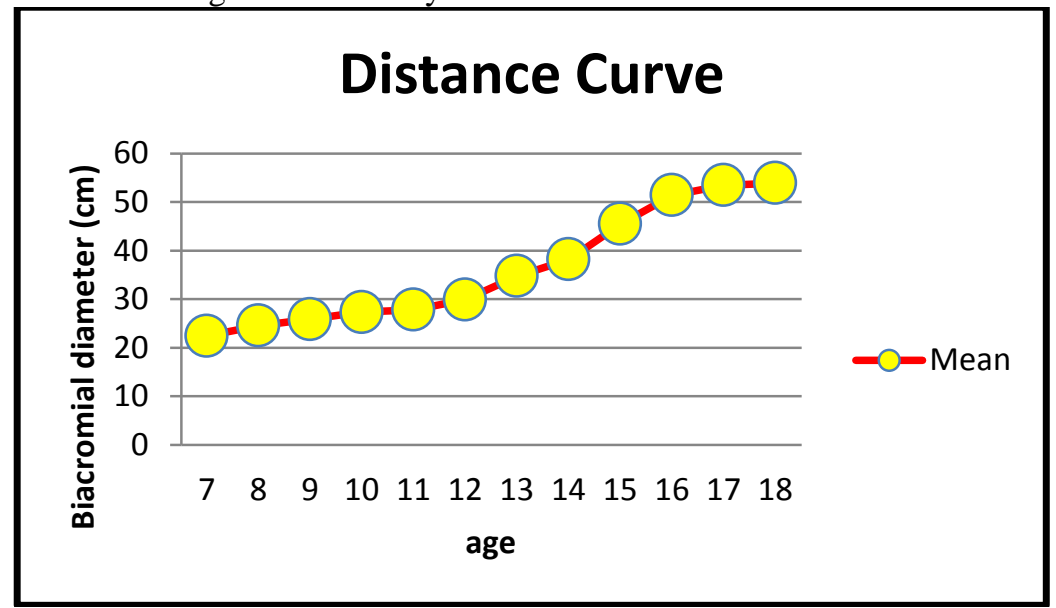

Figure3.2 Distance Curve for Biacromial Diameter

Table no. 3 gives the result for the biacromial diameter measurements for the present study. The biacromial diameter has a minimum value of $23.4 \mathrm{~cm}$ and maximum of $40.9 \mathrm{~cm}$. the maximum increment is at the age of 15 years with the value of $2.68 \mathrm{~cm}$. The velocity curve of biacromial diameter is shown in the figure 
3.1 shows that there is gradual decline at age 17 years onwards. The maximum increment is in the age 15 years with $2.68 \mathrm{~cm}$. It can be said that the growth spurt occurs at 15 years.

Maximum Hip Breadth:

Table4. Age group distribution of mean, SD, CV, Range and SEM for Maximum Hip Breadth (cm)

\begin{tabular}{|c|c|c|c|c|c|c|c|c|}
\hline $\begin{array}{c}\text { Age in } \\
\text { years }\end{array}$ & Mean & $\begin{array}{c}\text { Increment } \\
\text { per year }\end{array}$ & $\mathrm{N}$ & $\mathrm{SD}$ & $\mathrm{CV}$ & Min. range & Max. range & SEM \\
\hline 7 & 20.48 & & 18 & 1.76 & 3.11 & 17.1 & 23.2 & 0.41 \\
\hline 8 & 21.59 & 1.11 & 16 & 3.22 & 10.41 & 17.4 & 32.1 & 0.80 \\
\hline 9 & 22.49 & 0.90 & 17 & 1.39 & 1.93 & 19.5 & 24.8 & 0.33 \\
\hline 10 & 23.51 & 1.02 & 16 & 1.80 & 3.25 & 18.5 & 26.4 & 0.45 \\
\hline 11 & 24.83 & 1.31 & 16 & 1.67 & 2.81 & 22.4 & 28.1 & 0.41 \\
\hline 12 & 25.72 & 0.88 & 18 & 2.96 & 8.81 & 20.7 & 29.6 & 0.69 \\
\hline 13 & 26.71 & 0.99 & 15 & 3.54 & 12.56 & 18.5 & 31.5 & p.91 \\
\hline 14 & 28.46 & 1.75 & 16 & 1.43 & 2.07 & 25.9 & 31.5 & 4.35 \\
\hline 15 & 31.49 & 3.02 & 17 & 3.81 & 14.52 & 21.4 & 34.4 & 0.92 \\
\hline 16 & 32.74 & 1.25 & 17 & 1.79 & 3.21 & 29 & 34.4 & 0.43 \\
\hline 17 & 33.14 & 0.39 & 17 & 2.43 & 5.93 & 29.3 & 35.6 & 0.59 \\
\hline 18 & 33.69 & 0.55 & 17 & 3.20 & 10.27 & 23 & 35.8 & 0.77 \\
\hline Total & & & 200 & & & & \\
\hline
\end{tabular}

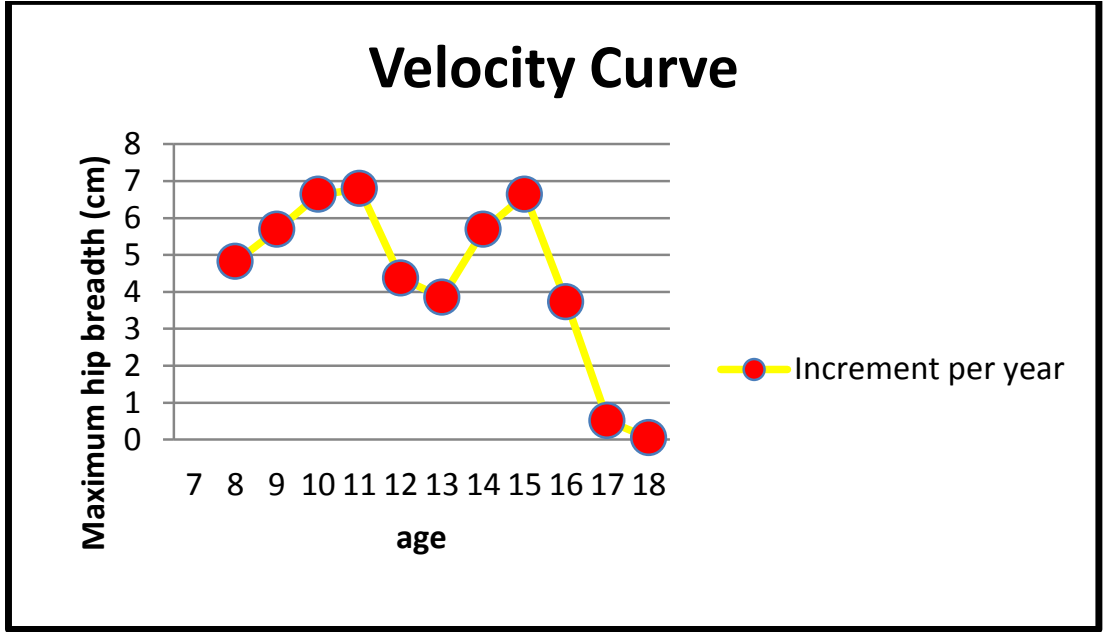

Figure4.1 Velocity Curve for Maximum Hip Breadth

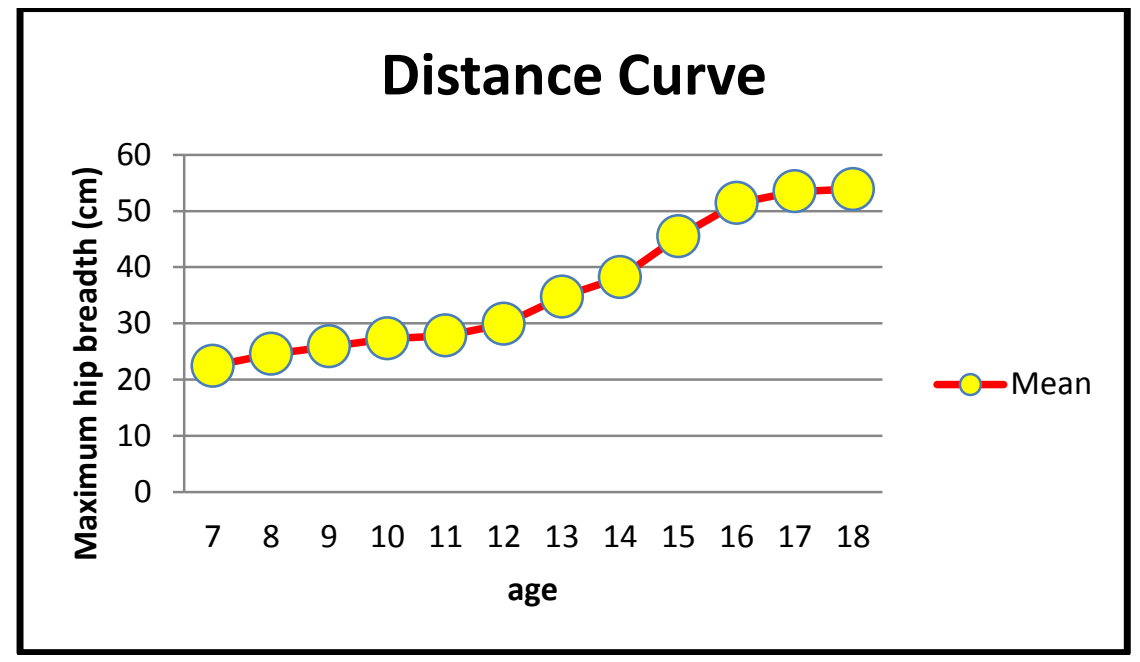

Figure4.2 Distance Curve for Maximum Hip Breadth

Maximum hip breadth, distance curve and velocity curve is given in figure 4.2 and 4.1 respectively with the data shown in Table no. 4. The minimum recorded hip breadth circumference is $17.1 \mathrm{~cm}$ while the highest is $35.8 \mathrm{~cm}$. There is slow and gradual increase of hip breadth with the increase in age. 
From the velocity curve it is clear that the maximum gained in hip breadth is at the age 15 years by $3.02 \mathrm{~cm}$. There is not much of fluctuation in hip breadth growth rate. It can be said that the growth spurt occurs at 15 years.

Upper Arm Circumference:

Table5. Age group distribution of mean, SD, CV, Range and SEM for Upper Arm Circumference (cm)

\begin{tabular}{|c|c|c|c|c|c|c|c|c|}
\hline $\begin{array}{c}\text { Age in } \\
\text { years }\end{array}$ & Mean & $\begin{array}{c}\text { Increment } \\
\text { per year }\end{array}$ & $\mathrm{N}$ & $\mathrm{SD}$ & $\mathrm{CV}$ & $\begin{array}{c}\text { Min. } \\
\text { range }\end{array}$ & $\begin{array}{c}\text { Max. } \\
\text { range }\end{array}$ & SEM \\
\hline 7 & 15.26 & & 18 & 2.62 & 6.87 & 12.8 & 23.7 & 0.61 \\
\hline 8 & 16.88 & 1.62 & 16 & 4.90 & 24.02 & 12.8 & 30.4 & 1.22 \\
\hline 9 & 17.46 & 0.57 & 17 & 2.03 & 4.12 & 13.7 & 21.8 & 0.49 \\
\hline 10 & 18.8 & 1.33 & 16 & 1.26 & 1.60 & 15.9 & 20.8 & 0.31 \\
\hline 11 & 20.23 & 1.43 & 16 & 2.49 & 6.23 & 17.5 & 24.6 & 0.62 \\
\hline 12 & 21.60 & 1.37 & 18 & 4.47 & 20.00 & 16.1 & 24.8 & 1.05 \\
\hline 13 & 22.16 & 0.56 & 15 & 3.21 & 10.3 & 17.4 & 27.3 & 0.82 \\
\hline 14 & 23.20 & 1.03 & 16 & 3.10 & 9.64 & 19 & 29.5 & 0.77 \\
\hline 15 & 25.82 & 2.61 & 17 & 2.61 & 6.81 & 21.5 & 30.1 & 0.63 \\
\hline 16 & 29.17 & 3.35 & 17 & 3.34 & 11.19 & 22.5 & 35.2 & 0.81 \\
\hline 17 & 30.51 & 1.34 & 17 & 2.45 & 6.04 & 27.2 & 36.1 & 0.59 \\
\hline 18 & 31.97 & 1.45 & 17 & 3.42 & 11.73 & 22.8 & 35.6 & 0.83 \\
\hline Total & & & 200 & & & & & \\
\hline
\end{tabular}

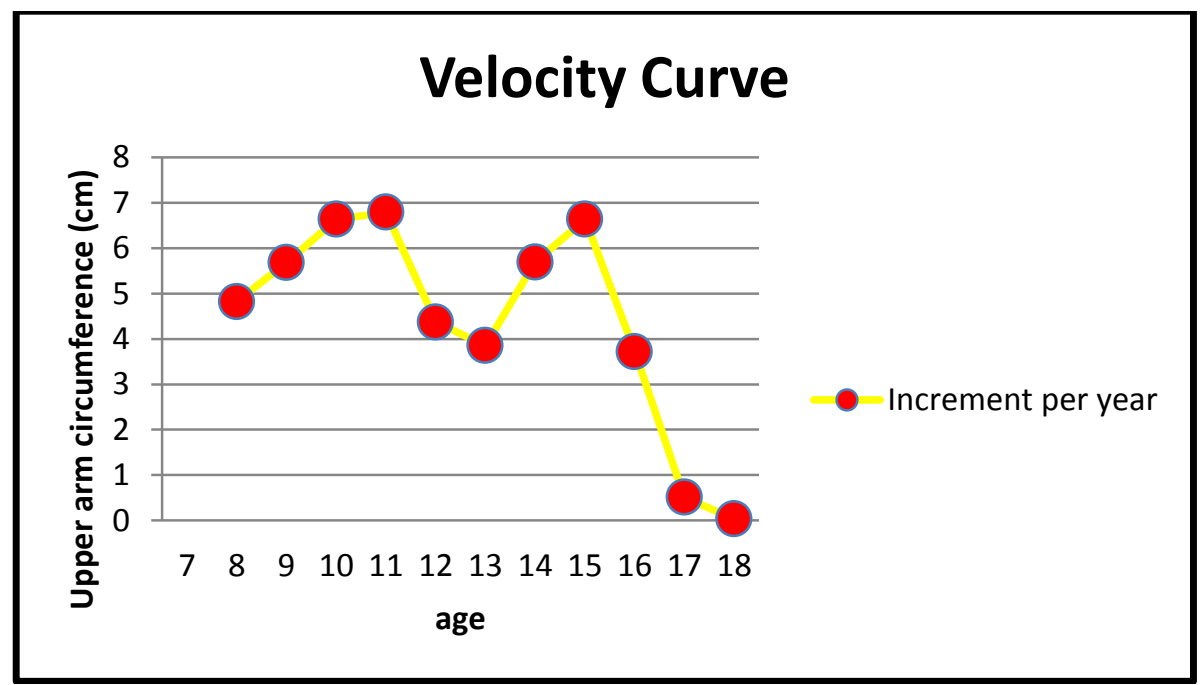

Figure5.1 Velocity Curve for Upper Arm Circumference

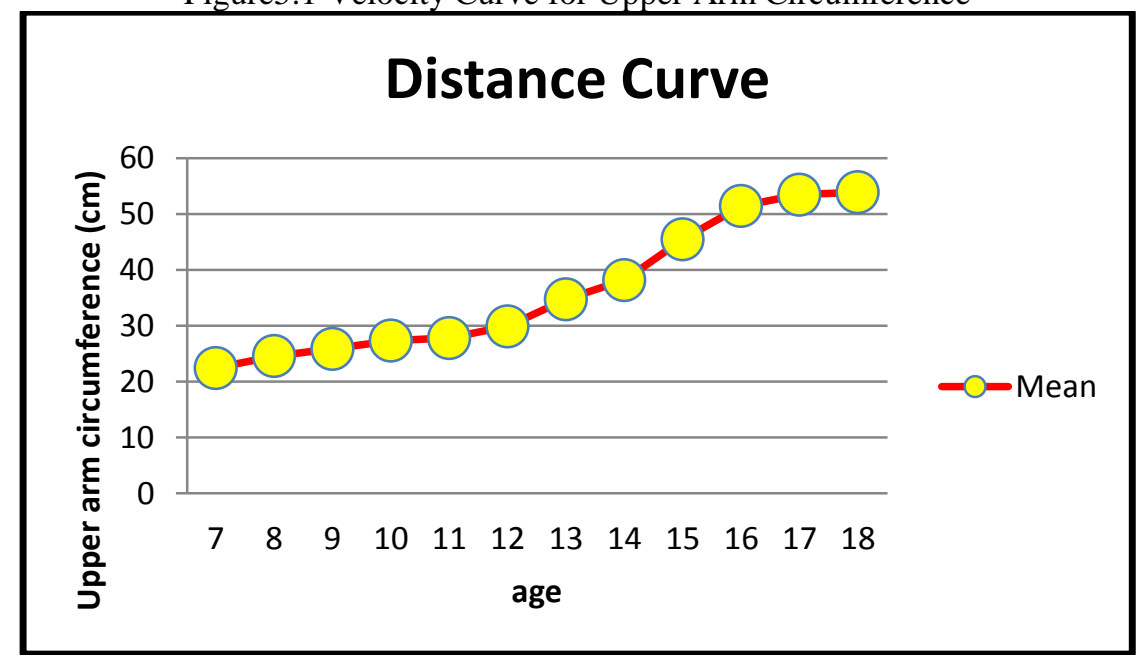

Figure5.2 Distance Curve for Upper Arm Circumference

The distance curve and velocity curve for upper arm circumference is given in figure no. 5.2 and 5.1 respectively with the calculated values given in table no. 5. It is observed that the mid upper arm circumference 
growth rate increases slowly and gradually with the increase in age from 7 to 18 years. The maximum increment is obtained at the age 16 years. The velocity curve shows sharp decrease in growth rate at age 9 years and 13 years and the maximum growth rate is at the age 16 years with an increment of $3.34 \mathrm{~cm}$.

Head Circumference:

Table6. Age group distribution of mean, SD, CV, Range and SEM for Head Circumference (cm)

\begin{tabular}{|c|c|c|c|c|c|c|c|c|}
\hline Age in years & Mean & $\begin{array}{c}\text { Increment } \\
\text { per year }\end{array}$ & $\mathrm{N}$ & $\mathrm{SD}$ & $\mathrm{CV}$ & Min. range & Max. range & SEM \\
\hline 7 & 50.62 & & 18 & 1.28 & 1.64 & 48.3 & 53.7 & 0.3 \\
\hline 8 & 50.74 & 0.11 & 16 & 3.11 & 9.70 & 40.8 & 56.8 & 0.77 \\
\hline 9 & 51.97 & 1.22 & 17 & 1.09 & 1.19 & 50.7 & 55.5 & 0.26 \\
\hline 10 & 52.71 & 0.74 & 16 & 1.38 & 1.92 & 50.5 & 55.9 & 0.34 \\
\hline 11 & 53.30 & 0.59 & 16 & 1.93 & 3.73 & 49.5 & 56 & 0.48 \\
\hline 12 & 54.21 & 0.91 & 18 & 1.97 & 3.91 & 51.8 & 58.1 & 0.46 \\
\hline 13 & 54.8 & 0.58 & 15 & 1.46 & 2.15 & 52.5 & 56.9 & 0.37 \\
\hline 14 & 55.18 & 0.38 & 16 & 1.45 & 2.12 & 53.7 & 59 & 0.36 \\
\hline 15 & 56.84 & 1.66 & 17 & 0.68 & 0.47 & 55.3 & 58.3 & 0.16 \\
\hline 16 & 57.58 & 0.74 & 17 & 1.87 & 3.51 & 53.7 & 59.4 & 0.45 \\
\hline 17 & 58.05 & 0.47 & 17 & 1.68 & 2.83 & 53.7 & 59.7 & 0.4 \\
\hline 18 & 58.91 & 0.85 & 17 & 1.62 & 2.63 & 55 & 60.2 & 0.39 \\
\hline Total & & & 200 & & & & \\
\hline
\end{tabular}

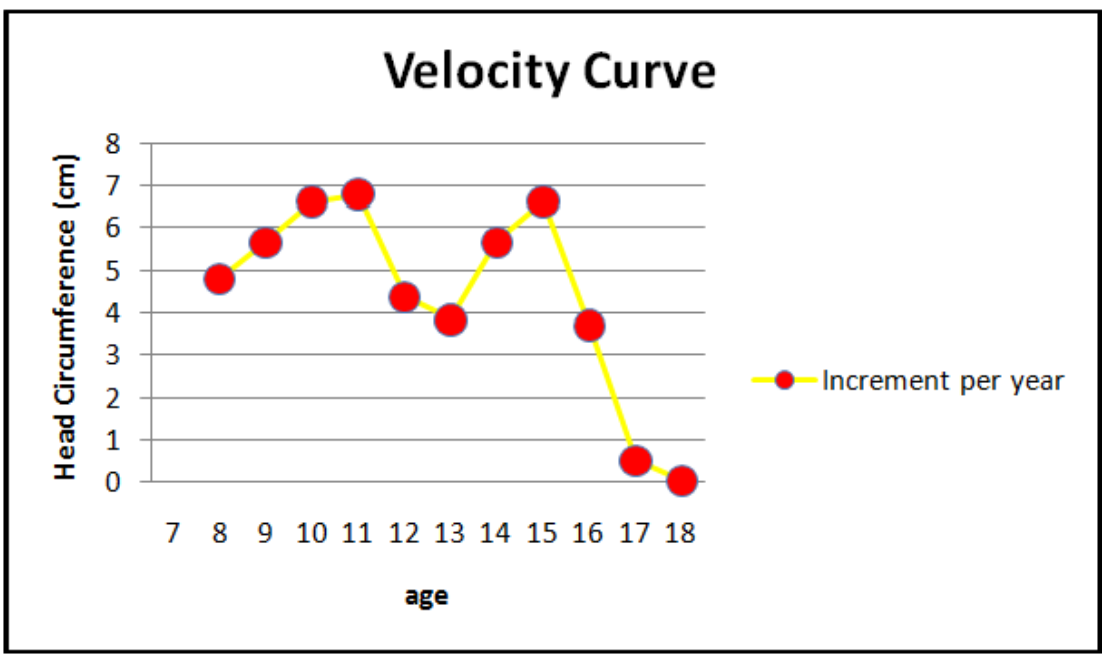

Figure6.1 Velocity Curve for Head Circumference

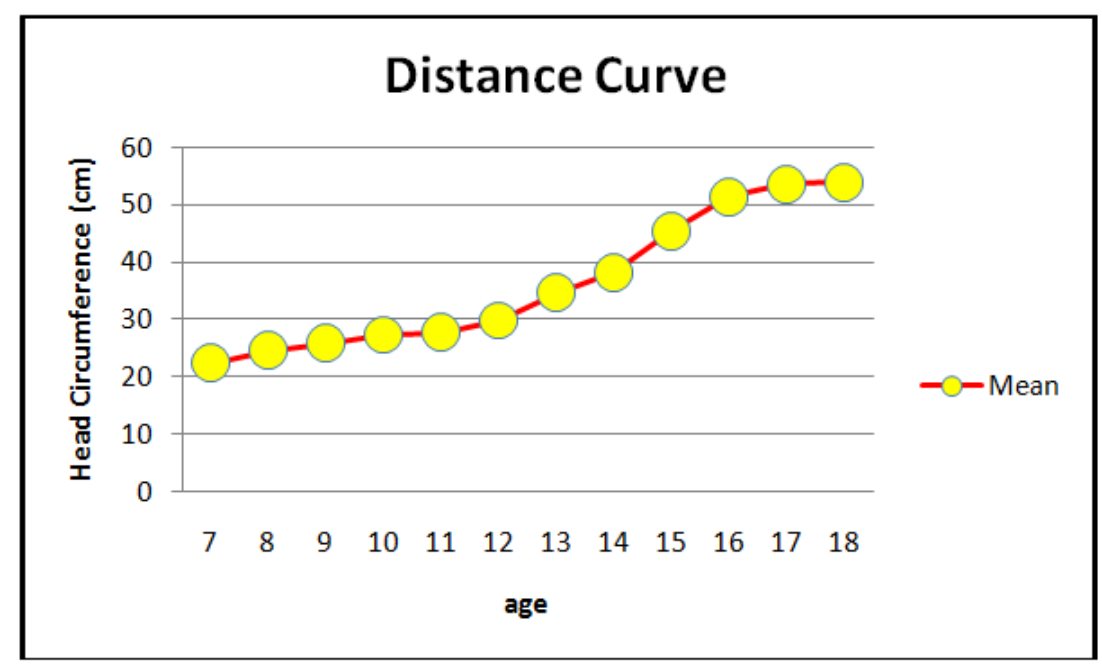

Figure6.2 Distance Curve for Head Circumference

Table no. 6 and figure no. 6.1 and 6.2 shows the measurement and calculated values of head circumference. The head circumference shows a gradual increase with increase in age. The mean difference is greatest at the age group 15 years. The maximum and minimum distribution of head circumference is $60.2 \mathrm{~cm}$ 
and $48.3 \mathrm{~cm}$ respectively. The growth per year of the subjects as in velocity curve and in table gives a fluctuated increase and decrease throughout the age group 7 to 18 years. The head circumference decreases sharply at age 14 years and then rises at the age 15 years. The peak velocity is seen at the age 15 years. It can be said that the growth spurt occurs at 15 years.

Weight:

Table7. Age group distribution of mean, SD, CV, Range and SEM for Weight $(\mathrm{kg})$

\begin{tabular}{|c|c|c|c|c|c|c|c|c|}
\hline $\begin{array}{c}\text { Age in } \\
\text { years }\end{array}$ & Mean & $\begin{array}{c}\text { Increment } \\
\text { per year }\end{array}$ & $\mathrm{N}$ & SD & CV & Min. range & Max. range & SEM \\
\hline 7 & 22.44 & & 18 & 1.14 & 1.32 & 20 & 24 \\
\hline 8 & 24.55 & 1.80 & 16 & 0.68 & 0.46 & 23 & 0.27 \\
\hline 9 & 25.88 & 1.63 & 17 & 1.4 & 1.98 & 23 & 25 & 0.17 \\
\hline 10 & 27.31 & 1.43 & 16 & 1.35 & 1.82 & 25 & 29 & 0.34 \\
\hline 11 & 27.81 & 0.5 & 16 & 1.1 & 1.22 & 26 & 30 & 0.27 \\
\hline 12 & 29.88 & 2.07 & 18 & 1.02 & 1.04 & 28 & 32 & 0.24 \\
\hline 13 & 34.73 & 4.84 & 15 & 2.49 & 6.2 & 30 & 38 & 0.64 \\
\hline 14 & 38.18 & 3.45 & 16 & 0.98 & 0.96 & 40 & 43 & 0.24 \\
\hline 15 & 45.47 & 7.28 & 17 & 2.23 & 5.01 & 43 & 51 & 0.54 \\
\hline 16 & 51.41 & 5.94 & 17 & 1.37 & 1.88 & 49 & 54 & 0.33 \\
\hline 17 & 53.47 & 2.05 & 17 & 1.66 & 2.76 & 51 & 56 & 0.40 \\
\hline 18 & 53.88 & 0.41 & 17 & 0.69 & 0.48 & 53 & 55 & 0.16 \\
\hline Total & & & 200 & & & & 56 \\
\hline
\end{tabular}

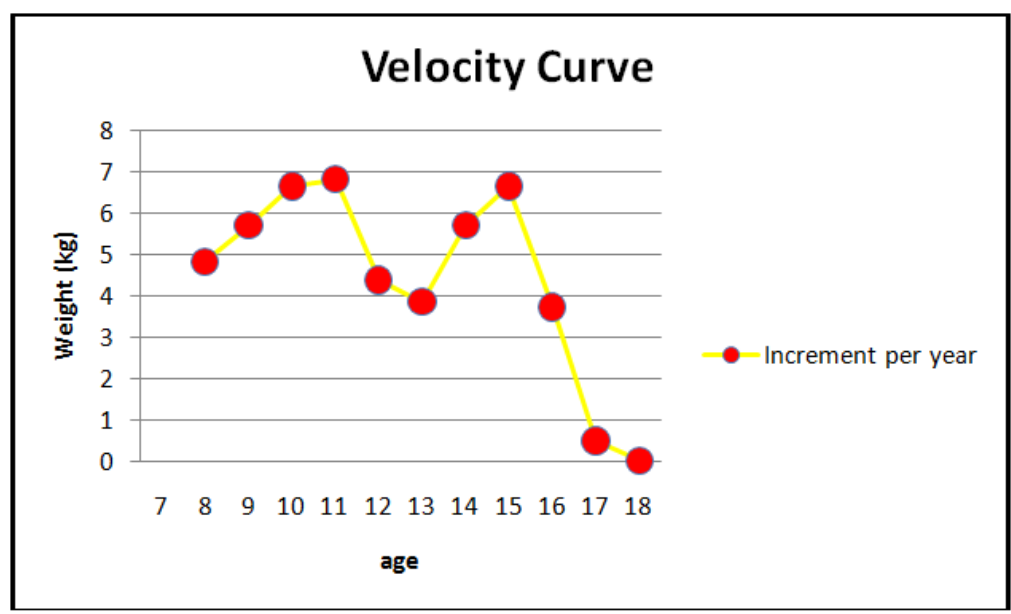

Figure7.1 Velocity Curve for Weight

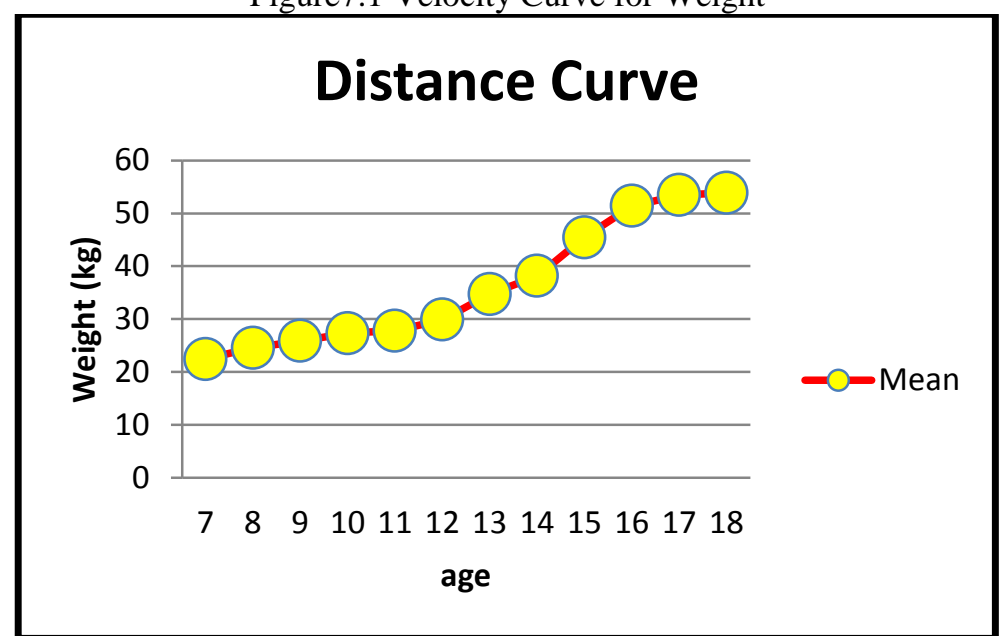

Figure7.2 Distance Curve for Weight

Weight distance curve and velocity curve is given in the figure 6.2 and figure 6.1 respectively and the data in table no. 7. The velocity curve indicates the growth rate per year in the Chakhesang boy's gained weight from 7 to 18 years. There is a sharp decrease in growth rate at the age 11 years and the increment at that year is $0.5 \mathrm{~kg}$ and the maximum increment in growth rate at the age 15 years by $7.28 \mathrm{~kg}$. It can be said that the growth spurt occurs at 15 years. 


\section{Nutritional Anthropometry}

Table8: Nutritional status according to BMI

\begin{tabular}{|c|c|c|c|}
\hline Nutritional Status & Ranges & No. of Individuals & Percentage \\
\hline Normal & $>-2$ Z-Score & 200 & 100 \\
\hline Moderate & $<-2$ to -3 Z-Score & 0 & 0 \\
\hline Severe & $<-3$ Z-Score & 0 & 0 \\
\hline & & 200 & 100 \\
\hline
\end{tabular}

Table9: Nutritional status according to Weight for Age

\begin{tabular}{|c|c|c|c|}
\hline Nutritional Status & Ranges & No. of Individuals & Percentage \\
\hline Normal & $>-2$ Z-Score & 200 & 100 \\
\hline Moderate & $<-2$ to -3 Z-Score & 0 & 0 \\
\hline Severe & $<-3$ Z-Score & 0 & 0 \\
\hline
\end{tabular}

Table10: Nutritional status according to Height for Age

\begin{tabular}{|c|c|c|c|}
\hline Nutritional Status & Ranges & No. of Individuals & Percentage \\
\hline Normal & $>-2$ Z-Score & 200 & 100 \\
\hline Moderate & $<-2$ to -3 Z-Score & 0 & 0 \\
\hline Severe & $<-3$ Z-Score & 0 & 0 \\
\hline
\end{tabular}

From the table 8, 9, and 10 shows the distribution of children according to different levels of nutritional status with respect to BMI (Body Mass Index), Weight for Age and Height for Age, following the Z-Score of -2 as a cut-off point. It can be seen that $100 \%$ are under normal condition and there is no condition of moderate or severe nutritional status. They are well nourished. It is also been seen that these children gaining their weight and height $100 \%$ according to their age, while no cases of moderate and severe nutritional status is found.

\section{Population Comparison}

The results of the present study are compared with the following earlier studies:

1. Established National Standard (ICMR, 1972) at $50^{\text {th }}$ percentile

2. Khasi boys of East Khasi Hills, Meghalaya (VizonuoPienyu, 2003)

3. Garo boys of Ri-bhoi District, Meghalaya (Zeneisalie Sano, 2006)

Table11: Population difference (t-values) for various measurements

\begin{tabular}{|c|c|c|c|c|c|c|c|c|c|c|}
\hline \multicolumn{11}{|c|}{ 4. $\quad$ Present study and ICMR } \\
\hline $\begin{array}{l}\text { Age in } \\
\text { years }\end{array}$ & & 10 & 11 & 12 & 13 & 14 & 15 & 16 & 17 & 18 \\
\hline $\begin{array}{l}\text { Height } \\
(\mathrm{cm})\end{array}$ & & 2.21 & 1.27 & 1.07 & 0.04 & 1.32 & 0.63 & 0.53 & -0.04 & -0.76 \\
\hline $\begin{array}{c}\text { Weight } \\
(\mathrm{kg})\end{array}$ & & $3.35^{*}$ & 1.52 & 1.38 & 1.94 & $3.66^{*}$ & $3.73^{*}$ & $4.08^{*}$ & $3.48^{*}$ & $3.71^{*}$ \\
\hline \multicolumn{11}{|c|}{ Present study and East Khasi boys } \\
\hline $\begin{array}{l}\text { Age in } \\
\text { years }\end{array}$ & 9 & 10 & 11 & 12 & 13 & 14 & 15 & 16 & 17 & 18 \\
\hline $\begin{array}{l}\text { Height } \\
(\mathrm{cm})\end{array}$ & & $2.60 *$ & $7.39 * *$ & $4.53^{* * *}$ & 0.84 & $2.58^{*}$ & $4.84 * *$ & $5.67 * *$ & $2.74 *$ & 1.78 \\
\hline $\begin{array}{l}\text { Weight } \\
(\mathrm{kg})\end{array}$ & & $4.35 *$ & $5.02 * *$ & 1.24 & -0.28 & $2.68 *$ & $4.32 * *$ & $10.4 * *$ & $3.81 * *$ & 0.99 \\
\hline \multicolumn{11}{|c|}{ Present study and Garo boys } \\
\hline $\begin{array}{l}\text { Age in } \\
\text { years }\end{array}$ & 9 & 10 & 11 & 12 & 13 & 14 & 15 & 16 & 17 & 18 \\
\hline $\begin{array}{l}\text { Height } \\
(\mathrm{cm})\end{array}$ & 1.62 & $4.84 * *$ & $9.83^{* *}$ & $4.13 *$ & -0.74 & $3.17 *$ & -1.72 & -0.18 & 0.64 & -0.03 \\
\hline $\begin{array}{l}\text { Weight } \\
(\mathrm{cm})\end{array}$ & $12.17 * *$ & $3.29 *$ & $2.98 *$ & 1.90 & $3.15^{*}$ & 1.52 & 1.38 & $3.82 *$ & 2.03 & -0.56 \\
\hline \multicolumn{11}{|c|}{$(* \mathrm{p}>0.05 \quad * * \mathrm{p}>0.001)$} \\
\hline
\end{tabular}

Comparing with ICMR at $50^{\text {th }}$ percentile, it is seen that the height vertex have no statistical differentiation at any ages. On the other hand the weight shows statistical differences at almost every age except at the age of 11,12 , and 13 years.

Comparing with Khasi boys of East Khasi hills, the height vertex shows statistical differences in almost all ages, except age 13 and 18 years and weight also show similar statistical differences in almost all ages except 12,13 , and 18 years. 
Comparing with Garo boys of Ri-bhoi district, the statistical differences in height vertex is only seen in age $10,11,12$, and 14 years. Whereas, the statistical differences of weight is distributed equally and can be observed in ages $9,10,11,13$, and 16 years.

Table12: Comparison of Height

\begin{tabular}{|c|c|c|c|c|c|c|c|c|c|c|c|c|}
\hline \multirow[t]{2}{*}{$\begin{array}{l}\text { Age } \\
\text { group }\end{array}$} & \multicolumn{3}{|c|}{ Present study } & \multicolumn{3}{|c|}{$\begin{array}{c}\text { Khasi boys (VizunuoPienyu, } \\
\text { 2003) }\end{array}$} & \multicolumn{3}{|c|}{$\begin{array}{c}\text { Garo boys (Zeneisalie Sano, } \\
\text { 2006) }\end{array}$} & \multicolumn{3}{|c|}{ ENS (ICMR) } \\
\hline & $\mathrm{N}$ & MEAN & SD & $\mathrm{N}$ & MEAN & SD & $\mathrm{N}$ & MEAN & SD & $\mathrm{N}$ & MEAN & SD \\
\hline 7 & 18 & 112.55 & 1.14 & & & & 16 & 112.5 & 4.08 & 3711 & 113.9 & 8.67 \\
\hline 8 & 16 & 117.38 & 0.77 & & & & 9 & 117.22 & 5.96 & 3957 & 119.3 & 7.34 \\
\hline 9 & 17 & 123.06 & 1.20 & & & & 10 & 121.43 & 3.67 & 3873 & 123.7 & 9.28 \\
\hline 10 & 16 & 129.70 & 1.47 & 9 & 121.91 & 11.32 & 9 & 123.5 & 4.5 & 4965 & 124.4 & 9.99 \\
\hline 11 & 16 & 136.49 & 2.25 & 10 & 123.97 & 5.86 & 5 & 125.43 & 1.48 & 3879 & 133.4 & 9.73 \\
\hline 12 & 18 & 140.87 & 2.24 & 9 & 129.08 & 10.13 & 6 & 135.58 & 3.46 & 4052 & 138.3 & 10.14 \\
\hline 13 & 15 & 144.72 & 2.38 & 9 & 142.34 & 9.93 & 3 & 145.9 & 2.26 & 3875 & 144.6 & 9.73 \\
\hline 14 & 16 & 153.41 & 1.73 & 7 & 145.5 & 11.4 & 8 & 149.83 & 3.57 & 3621 & 150.1 & 10.03 \\
\hline 15 & 17 & 157.05 & 1.17 & 7 & 147.63 & 7.47 & 3 & 158.43 & 1.46 & 3609 & 155.5 & 10.01 \\
\hline 16 & 17 & 160.77 & 3.99 & 7 & 150.22 & 3.92 & 3 & 161.25 & 3.85 & 3451 & 159.5 & 9.75 \\
\hline 17 & 17 & 161.28 & 3.17 & 9 & 156.9 & 4.43 & 2 & 162.82 & 0.75 & 3235 & 161.4 & 10.45 \\
\hline 18 & 17 & 161.32 & 3.79 & 18 & 158.81 & 4.28 & 9 & 163.66 & 4.61 & 3006 & 163.1 & 9.57 \\
\hline
\end{tabular}

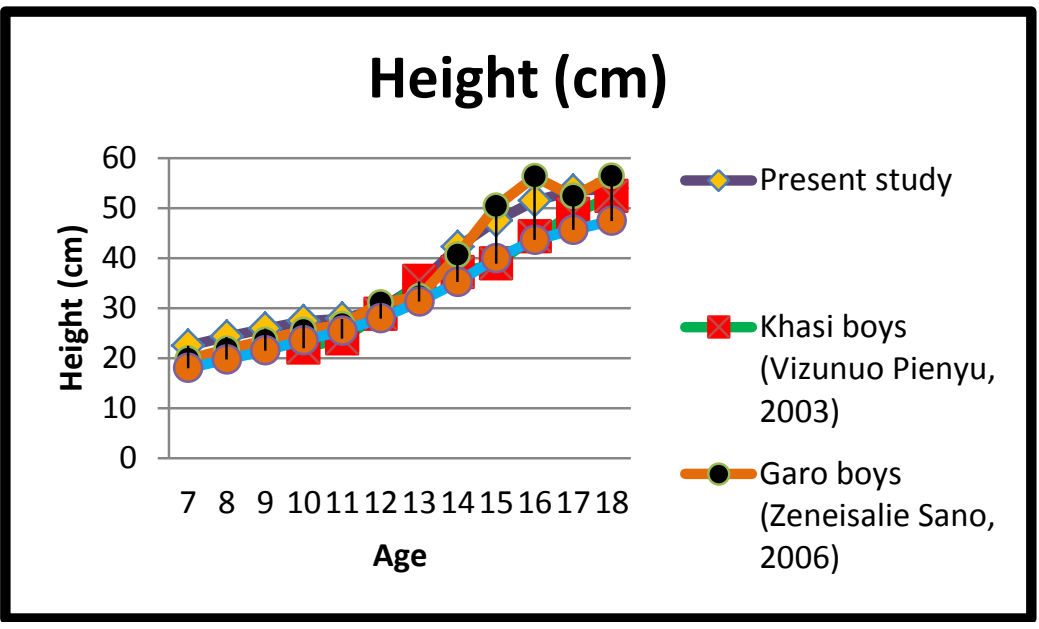

Figure8: Comparison of Mean Height

Height: It is seen from the figure no. 8 and table no. 12 that the present study population have similarity in height to that of ICMR at $50^{\text {th }}$ percentile and Garo boys while boys are found to be taller than the boys of the population studied. At the younger age all the populations are more or less similar but from age 9 years onwards drastic change is seen in the graph is observed where Khasi boys have make up their height comparing to the present study but however after the age of 15 years onwards this differences started to merge again.

Table 13: Comparison of Weight

\begin{tabular}{|c|c|c|c|c|c|c|c|c|c|c|c|c|}
\hline \multirow[t]{2}{*}{$\begin{array}{l}\text { Age } \\
\text { group }\end{array}$} & \multicolumn{3}{|c|}{ Present study } & \multicolumn{3}{|c|}{$\begin{array}{c}\text { Khasi boys (VizunuoPienyu, } \\
\text { 2003) }\end{array}$} & \multicolumn{3}{|c|}{$\begin{array}{c}\text { Garo boys (Zeneisalie Sano, } \\
\text { 2006) }\end{array}$} & \multicolumn{3}{|c|}{ ENS (ICMR) } \\
\hline & $\mathrm{N}$ & MEAN & SD & $\mathrm{N}$ & MEAN & SD & $\mathrm{N}$ & MEAN & SD & $\mathrm{N}$ & MEAN & SD \\
\hline 7 & 18 & 22.44 & 1.15 & & & & 16 & 19.81 & 1.42 & 3711 & 18 & 3.05 \\
\hline 8 & 16 & 24.25 & 0.68 & & & & 9 & 21.81 & 2.48 & 3957 & 19.7 & 3.37 \\
\hline 9 & 17 & 25.88 & 1.41 & & & & 10 & 23.5 & 1.96 & 3873 & 21.5 & 4.47 \\
\hline 10 & 16 & 27.31 & 1.35 & 9 & 22 & 4.32 & 9 & 25.55 & 0.95 & 4965 & 23.5 & 5.26 \\
\hline 11 & 16 & 27.81 & 1.11 & 10 & 23.88 & 2.66 & 5 & 26.66 & 0.94 & 3879 & 25.4 & 6.33 \\
\hline 12 & 18 & 29.89 & 1.02 & 9 & 28.77 & 3.38 & 6 & 31 & 2.13 & 4052 & 27.9 & 6.1 \\
\hline 13 & 15 & 34.73 & 2.49 & 9 & 35.33 & 6.96 & 3 & 32.25 & 3.34 & 3875 & 31.3 & 6.82 \\
\hline 14 & 16 & 42.19 & 0.98 & 7 & 37.14 & 7.03 & 8 & 40.62 & 2.1 & 3621 & 35.2 & 7.62 \\
\hline 15 & 17 & 47.47 & 2.24 & 7 & 38.85 & 7.05 & 3 & 50.33 & 3.36 & 3609 & 39.9 & 8.36 \\
\hline 16 & 17 & 51.41 & 1.37 & 7 & 44.28 & 1.66 & 3 & 56.25 & 1.25 & 3451 & 43.6 & 7.88 \\
\hline 17 & 17 & 53.47 & 1.66 & 9 & 48.77 & 4.18 & 2 & 52.33 & 0.47 & 3235 & 45.6 & 9.02 \\
\hline 18 & 17 & 53.88 & 0.70 & 18 & 52.37 & 6.04 & 9 & 56.33 & 3.93 & 3006 & 47.4 & 7.2 \\
\hline
\end{tabular}




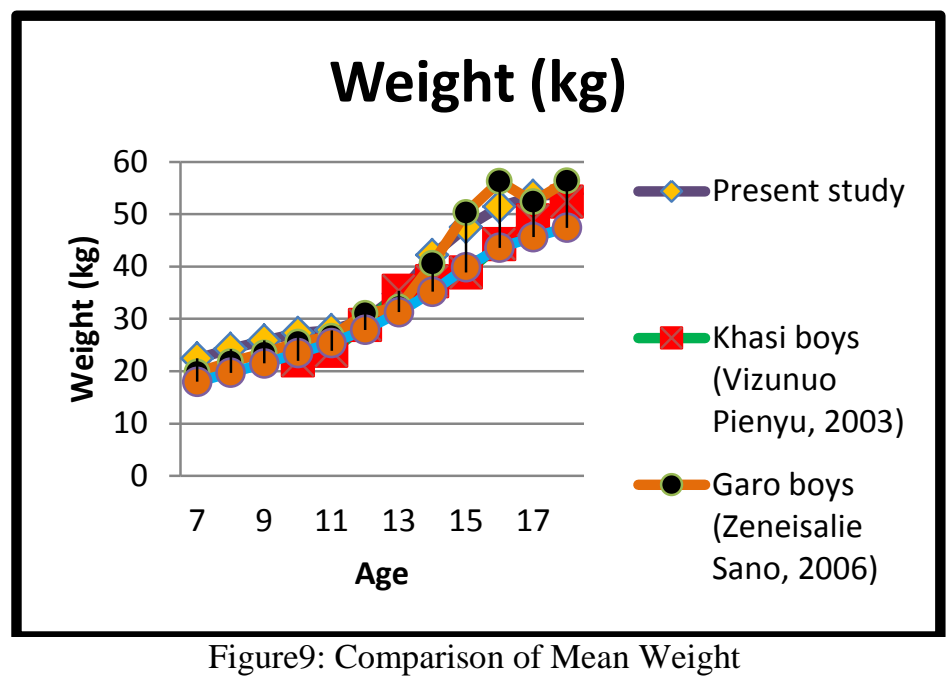

Weight: From the figure no. 9 and table no. 13, it is seen that the weight of the present study are much lighter than that of the Khasi boys and heavier than that of the ICMR at $50^{\text {th }}$ percentile. However, similarities are seen between the present studies and the Garo boys of Ri-bhoi district throughout the ages. While in the ages of 15 years and above we observed that the difference in the weight slightly demises with respect to the ICMR at $50^{\text {th }}$ percentile.

\section{The Major Findings}

1. The mean height of the Chakhesang boys shows a gradual increase with the increase in age, i.e. from age 7 to 18 years. Considering, all the age groups the minimum and maximum height obtained is $110.2 \mathrm{~cm}$ and $167 \mathrm{~cm}$ respectively. From 14 to 15 years, there is a sharp increase in height, which shows a maximum increase of $6.63 \mathrm{~cm}$. Thus, it indicates that the growth spurt occurs at the age of 15 years.

2. The mean sitting height increases from 7 to 18 years. The distribution of maximum and minimum sitting height is $89.2 \mathrm{~cm}$ and $51.2 \mathrm{~cm}$ respectively. The maximum increase in sitting height occurs between 14 and 15 years with the increment of $4.22 \mathrm{~cm}$ showing the growth spurt occurs at the age of 15 years.

3. The biacromial diameter shows a gradual increase with increasing age i.e. from 7 to 18 years. The distribution of maximum and minimum biacromial diameter is $40.9 \mathrm{~cm}$ and $23.4 \mathrm{~cm}$ respectively. The mean difference between the preceding and succeeding age groups is maximum in between 13 to 15 years i.e. $2.68 \mathrm{~cm}$. Thus, it indicates that the adolescent growth spurt occurs at 15 years.

4. The hip breadth gradually increases with an increasing age i.e. from age 7 to 18 years, except at the age of 18 years. The greatest mean difference occur at the age of 16 years. The distribution of maximum and minimum hip breadth is $35.8 \mathrm{~cm}$ and $17.1 \mathrm{~cm}$ respectively. A maximum gain in hip breadth occurs between 14 and 15 years with the increment of $3.02 \mathrm{~cm}$. Thus, it indicates that adolescence growth spurt occurs at the age of 15 years.

5. The upper arm circumference increases with increasing age. The greatest difference occurred at the age of 16 years. The distribution of maximum and minimum upper arm circumference is $35.6 \mathrm{~cm}$ and $12.8 \mathrm{~cm}$ respectively. A maximum gain in upper arm circumference occurs between 15 and 16 years with the increment of $3.35 \mathrm{~cm}$.

6. The head circumference increases with increasing age i.e. 7 to 18 years except at the age of 15 years. The distribution of maximum and minimum head circumference is $60.2 \mathrm{~cm}$ and $48.3 \mathrm{~cm}$ respectively. The maximum increment observed is $1.66 \mathrm{~cm}$ between the age group of 14 and 15 years.

7. The weight shows a steep increase with increasing age, i.e. from 7 to 18 years. Considering all the groups the maximum and minimum mean weight is $55 \mathrm{~kg}$ and $20 \mathrm{~kg}$ respectively. The peak increase is observed between the age 14 and 15 years with the increment of $7.28 \mathrm{~kg}$. Thus, indicating the adolescent growth spurt occurs at 15 years.

8. The maximum difference in age occurs between 14 to 15 years, in which most of the anthropometric measurements, shows high statistical significance.

9. As for the population comparison, the ICMR at $50^{\text {th }}$ percentile is seen to have statistical differentiation at ages 11, 12, and 13 years in weight. On the other hand, the height shows no statistical differentiation. Compare with the Khasi boys of East Khasi Hills, height vertex shows statistical differentiation at most of the ages except at 13 and 18 years. Statistical differentiation in weight is observed at all ages except 12, 13, and 18 years. As compared with Garo boys of Ri-bhoi District, height vertex shows statistical 
differentiation only in ages $10,11,12$, and 14 years. Whereas, statistical differentiation of weight is seen at ages $9,10,11,13$, and 16 years.

10. Nutritional status with respect to Body Mass Index (BMI), Weight for Age, and Height for Age following the Z-score of -2 as cut-off point gives $100 \%$ of normal condition of the present study. This signifies that the Chakhesang boys were well nourished.

11. Comparing the mean height of the present study with Khasi boys of East Khasi Hills, Garo boys of Ri-bhoi district and ICMR shows that present study population have similar height to that of ICMR and Garo boys while Khasi boys are found to be taller than the boys of present study. When compared in terms of mean weight present study shows similarity to that of ICMR and Garo boys while the weight is lower when compared with Khasi boys of East Khasi Hills.

\section{Conclusion}

With the objectives for the present study, it can be concluded as follows:

1. Anthropometric measurements i.e. height vertex, sitting height, biacromial diameter, maximum hip breadth, upper arm circumference, head circumference, and weight shows increment in growth of Chakhesang boys within the age group 7-18 years corresponding with their age and thus follow the growth patterns.

2. Nutritional status according to BMI, Weight for Age and Height for Age shows that the Chakhesang boys within the age group of 7-18 years are well nourished and healthy.

3. It is found that the present studied population does not show much deviation from the other population of earlier studies i.e. the Garo boys of Ri-bhoi district, Meghalaya and ICMR. However, deviation is observed with respect to Khasi boys of East Khasi Hills, which shows much higher growth rate than the present population studied.

This normal growth and well nutritional status is the outcome of the positive environmental condition of the surroundings. The village is close to the market area where access to daily needs such as groceries, vegetables, other eatables along with other necessities such as educational institute and medical facilities is available. Nevertheless, this better environmental condition helps in the proper growth of the children.

\section{References}

[1] Calder, P.C. and Jackson, A.A. (2000). Under Nutrition, Infection and Immune Function.Nutrition Research Review, 13: 3-29.

[2] Castilla, L.V. and M.M. Lahr. (2001). Secular Trend of Growth among Urban Brazilian Children of European Descent. Annals of Human Biology, 28 (5): 564-567.

[3] Choudhary, B. (1979): A Cross Sectional Study of Growth of some Somatometric Characters of Rabha Boys of Kamrup, Assam. PhD. Thesis, Guwahati University.

[4] Das, H. (1998). Age Changes in some Somatometric Characters of the Hajong of Meghalaya.PhD. Thesis, Guwahati University.

[5] Das, P.B. (1992). A Mixed Longitudinal Study in Height and Weight of Assamese Children from 8-10 years. Bulletin of the Department of Anthropology, Guwahati University.

[6] Das, P.B. and Choudhary, B. (1992). A Mixed Longitudinal Study on Growth in Height and Weight of Assamese Children from 110 years. Bulletin of Anthropological Survey of India, 31(3\&4): 37-42.

[7] Eveleth, P.B. and Tanner, J.M. (1990). Worldwide Variation on Human Growth.2 ${ }^{\text {nd }}$ edition. Cambridge: Cambridge University Press.

[8] Ghosh, S. (2004).Child Malnutrition. Economic and Political Weekly, 39:4412-4413.

[9] Garn, S.M (1952). Physical Growth and Development.American Journal of Physical Anthropology,10: 169-192.

[10] Garn, S.M. (1966). Nutrition in Physical Anthropology.American Journal of Physical Anthropology, 24: $289-292$.

[11] I.C.M.R (1972).Growth and Physical Development of Indian Infants and Children.I.C.M.R technical reports series no. 18. New Delhi: I.C.M.R.

[12] Khongsdier, R. (1996). Growth Pattern of War Khasi Children of Meghalaya.Journal of Human Ecology, 7(3): 175-180.

[13] Medhi, G.K.; Barua, A. and Mahanta, J. (2006).Growth and Nutritional Status of School Age Children (6-14) of Tea Garden Worker of Assam.Journal of Human Ecology, 19(2): 83-85.

[14] Mukherjee, N. (2002). Study on Demography and Growth Pattern Among the Khasi Children of Shillong, Meghalaya. Unpublished $\mathrm{PhD}$. Thesis of NEHU.

[15] National Family Health Survey-II (1998-99). North Eastern States.Mumbai International Institute of Population Science.

[16] Sengupta, S. and Singh, J. (2007).Nutritional Status of SonowalKachari Children of Dibrugarh District, Assam.Anthropologists, 9(3): 233-235.

[17] W.H.O (1990).Diet, Nutrition and the Prevention of Chronic Disease.W.H.O technical reports series no. 797. W.H.O Geneva.

[18] W.H.O (1995).Physical Status: The Use and Interpretation of Anthropometry.W.H.O technical reports series no. 854. W.H.O Geneva. 